\title{
Espiritualidade e Subjetividade: a provocação de Michel Foucault e a Teologia em tempos pós-modernos
}

\author{
Orientadora: Maria Clara Lucchetti Bingemer \\ Doutorando: Irenio Silveira Chaves \\ Área de Concentração: Teologia Sistemático-Pastoral \\ Linha de Pesquisa: Religião e Modernidade
}

O presente trabalho tem como objetivo investigar em que medida é possível desenvolver uma compreensão teológica que tenha como pressuposto a abordagem sobre as técnicas de si empreendidas por Michel Foucault em sua última fase, principalmente em sua obra A hermenêutica do sujeito. Para isso, é feita uma articulação entre os temas da espiritualidade e da subjetividade, uma vez que os mesmos estão presentes no pensamento foucaultiano como possibilidades de acesso à verdade. Diante do quadro de crises em que se configura a pós-modernidade, Foucault apresenta provocações para a teologia no que diz respeito à pastoral e às relações que envolvem saber e poder. Sua crítica está voltada para as técnicas de subjetivação que visam exercer controle sobre o indivíduo, transformando-o em um sujeito obediente a uma autoridade que visa estabelecer um saber que deve ser acolhido como verdade. A espiritualidade cristã, que se constitui a partir da apropriação do pensamento greco-romano, é marcada por uma moral austera e conduz a uma prática de si que exige uma hermenêutica que leve em conta a interioridade do sujeito. Essa mesma espiritualidade enfrenta um divórcio com a teologia na modernidade, provocando o surgimento do sujeito fragmentado na contemporaneidade. A pesquisa também procura fazer uma aproximação com a teologia de Jürgen Moltmann, principalmente com respeito à ação pastoral, à teologia voltada para o diálogo inter-religioso e para a práxis que tenha por finalidade a libertação do ser humano de sua situação de opressão e de alienação.

Palavras-chave: Teologia; espiritualidade; subjetividade, pós-modernidade. 